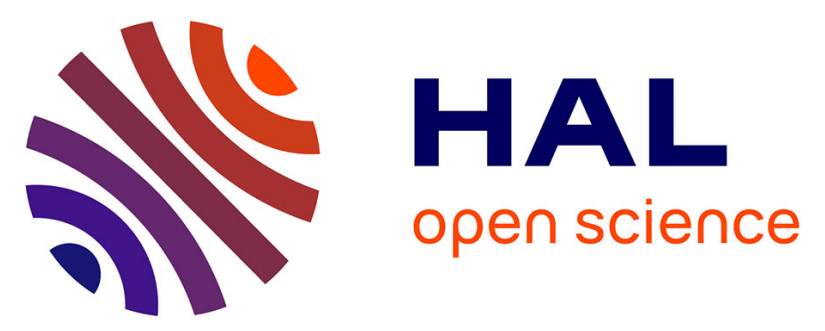

\title{
Cationic versus anionic Pt complex The performance analysis of a hybrid-capacitor, DFT calculation and electrochemical properties
}

\author{
M. Akkoç, S. Demirel, E. Öz, S. Altin, A. Bayri, V. Dorcet, T. Roisnel, \\ Christian Bruneau, I. Özdemir, S. Yaşar
}

\section{To cite this version:}

M. Akkoç, S. Demirel, E. Öz, S. Altin, A. Bayri, et al.. Cationic versus anionic Pt complex The performance analysis of a hybrid-capacitor, DFT calculation and electrochemical properties. Polyhedron, 2019, 157, pp.434-441. 10.1016/j.poly.2018.10.033 . hal-01939029

HAL Id: hal-01939029

https://hal-univ-rennes1.archives-ouvertes.fr/hal-01939029

Submitted on 6 Dec 2018

HAL is a multi-disciplinary open access archive for the deposit and dissemination of scientific research documents, whether they are published or not. The documents may come from teaching and research institutions in France or abroad, or from public or private research centers.
L'archive ouverte pluridisciplinaire HAL, est destinée au dépôt et à la diffusion de documents scientifiques de niveau recherche, publiés ou non, émanant des établissements d'enseignement et de recherche français ou étrangers, des laboratoires publics ou privés. 


\title{
Cationic versus anionic Pt complex: The performance analysis of a hybrid- capacitor, DFT calculation and electrochemical properties
}

\author{
Mitat Akkoç, ${ }^{a}$ Serkan Demirel,,${ }^{b, c}$ Erdinç Öz, ${ }^{b, d}$ Serdar Altın, ${ }^{b, *}$ Ali Bayri, ${ }^{b}$ Vincent \\ Dorcet, ${ }^{e}$ Thierry Roisnel, ${ }^{e}$ Christian Bruneau, ${ }^{e}$ Ismail Özdemir, ${ }^{a}$ Sedat Yaşar ${ }^{a}, *$
}

\author{
a İnönü University, Faculty of Science and Art, Department of Chemistry, 44280, Malatya, Turkey

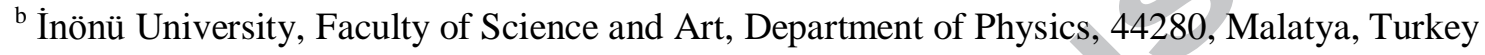 \\ ${ }^{\mathrm{c}}$ National Defense University, Naval Petty Officer Vacational School, Yalova, Turkey \\ d Ankara University, Institute of Accelerator Technologies, Ankara, 06830, Turkey \\ ${ }^{\text {e }}$ Université de Rennes, UMR 6226: CNRS Sciences Chimiques de Rennes, 35042, France
}

\begin{abstract}
The synthesis and characterization of cationic versus anionic platinum(II) complex of the type $\left[\mathrm{PtCl}_{3}(\mathrm{DMSO})\right]^{-}[\mathrm{NHC}]^{+}$(NHC: $\mathrm{N}$-heterocyclic carbene) is reported for the first time. The complex 3 was synthesized from silver(I)-NHC 2, and $\mathrm{K}_{2}\left[\mathrm{PtCl}_{4}\right]$ in DMSO at $80{ }^{\circ} \mathrm{C}$ under exclusion of light. The ionic platinum(II) complex was obtained in high yield and fully characterized by ${ }^{1} \mathrm{H},{ }^{13} \mathrm{C},{ }^{195} \mathrm{Pt}$ NMR and HRMS spectroscopy, X-ray diffraction and elemental analysis. The structural properties of the complex were investigated by using Gaussian suit and the obtained parameters were crosschecked with the X-ray data. The HOMO-LUMO energies and electrostatic surface mapping of the complex were calculated and the results were discussed with the capacitive properties of the complex. Electrochemical analysis by cyclic voltammetry $(\mathrm{CV})$ of the complex shows reversible redox peaks about platinum center. The complex was used as an electrode material for the capacitor device and result is promising that the highest performance of complex 3 was found as $10.22 \mathrm{~F} / \mathrm{g}$.
\end{abstract}


Corresponding Authors: Sedat Yaşar, Tel:+904223773735, Fax:+904223410212, e-mail:sedat.yasar@inonu.edu.tr; Serdar Altın, email: serdar.altin@inonu.edu.tr

Keywords:Platinum ionic complex; ring-expanded $N$-heterocyclic carbene; hybrid capacitor; DFT

\section{Introduction}

Energy production and storage getting more attention lately from the scientists and technology firms. The production of the energy involves usage of new effective sources such as solar cell and wind energy. In addition to this, we see that the storage techniques are also important especially for portable devices and electric vehicles. In the study of energy technologies, it is seen that the new capacitors which named as hybrid or supercapacitors take an attention at this field. It is known that the storage capacity of the cells is related to the surface area and conducting mechanism of the electrode materials [1]. In addition to this, electrolyte materials are also important for the improving the capacity of the cells. It should be noted that graphene based electrode materials shows high capacity when compared with the other materials. The electronic technology needs different capacitive value of the cells and the intrinsic properties of hybrid capacitors such as high capacity value of $4-250 \mathrm{Fg}^{-1}$ have gained considerable attention [2]. The scientists have been trying to find new electrode materials to provide the demands of the electronic sectors. The first study for capacitor device applications of organic complex was performed before to 20th century [3a-c]. The organometallic complexes may be a potential electrode material for production of hybrid capacitors [3d]. Since they may provide higher surface area when compared the other electrode materials. The metal ions in organometallic complex can change the valence state which may provide extra electrochemical properties for the energy storage applications.

Last few decades, distinctive chemistry of $\mathrm{N}$-heterocyclic carbenes (NHCs) were made them one of the most important ligands in organometallic chemistry and catalysis [4]. NHC's strong $\sigma$-donor and weak $\pi$-acceptor bond properties bring about 
more stable metal-ligand bond than many other classes of ligand [5]. The ringexpanded NHCs (re-NHCs), which exhibit different properties, are the types of NHC ligands. Recently, research groups have focused on to explore their properties. The reNHCs contribute to a significant increase in donor ability and steric hindrance to the metal center than their 5 membered analogues. Thus, these unique properties of ringexpanded-NHCs made them useful ligands in various research areas $[6,7]$. The pioneer works in this topic were reported by Stahl and Cavell groups. Cavell et all. and other research groups have published their works on synthesis and catalytic application of ring expanded $N$-heterocyclic carbene complexes [6-10].

Herein, we report the synthesis, characterization, DFT calculation and electro chemical properties of $\left[\mathrm{PtCl}_{3}(\mathrm{DMSO})\right]^{-}[\mathrm{NHC}]^{+}$type complex. Also, for the first time, the hybrid capacitor property of this type of complex has been investigated.

\section{Experimental Section}

\subsection{General remarks}

Unless stated otherwise, all manipulations were performed under an argon atmosphere. Chemicals were purchased from Sigma Aldrich Co. (Dorset, UK) and used as handled. Solvents of analytical grade were freshly distilled using an MBraun SPS-800 machine. Mass spectra were recorded by electron spray ionization (ESI) method. The ${ }^{1} \mathrm{H}$ and ${ }^{13} \mathrm{C}$ NMR spectra were recorded with a Bruker Avance III 300 or $400 \mathrm{MHz}$ NMR spectrometer with sample solutions prepared in $\mathrm{CDCl}_{3}$. The chemical shifts were reported in $\delta$ units downfield from the internal reference $\left(\mathrm{Me}_{4} \mathrm{Si}\right)$ as seen in Figure S1. Coupling constants ( $J$ values) are given in hertz. NMR multiplicities are abbreviated as follows: $\mathrm{s}=$ singlet, $\mathrm{d}=\mathrm{doublet}, \mathrm{t}=$ triplet, $\mathrm{m}=$ multiplet, $\mathrm{bs}=$ broad singlet.

\subsection{Single crystal analysis}


$\left(\mathrm{C}_{29} \mathrm{H}_{43} \mathrm{~N}_{2}, \mathrm{C}_{2} \mathrm{H}_{6} \mathrm{Cl}_{3} \mathrm{OPtS}\right) ; M=799.22$. D8 VENTURE Bruker AXS diffractometer [*], Mo$\mathrm{K} \alpha$ radiation $(\lambda=0.71073 \AA), T=150 \mathrm{~K}$; monoclinic $P 2{ }_{1} / c($ I.T.\#14), $\mathrm{a}=10.9339(11), \mathrm{b}=$ 17.1182(19), $\mathrm{c}=17.790(2) \AA, \beta=93.129(4){ }^{\circ}, V=3324.8(6) \AA^{3} . Z=4, d=1.597 \mathrm{~g} \cdot \mathrm{cm}^{-3}, \mu=$ $4.551 \mathrm{~mm}^{-1}$. The crystal structure was solved by direct methods using the SHELXT program [11], and then refined with full-matrix least-squares method based on $F^{2}$ (SHELXL-2014) [12]. All non-hydrogen atoms were refined with anisotropic atomic displacement parameters. $\mathrm{H}$ atoms were finally included in their calculated positions. A final refinement on $F^{2}$ with 7621 unique intensities and 362 parameters converged at $\mathrm{w} R\left(F^{2}\right)=0.0802(R(F)=0.0306)$ for 6521 observed reflections with $I>2 \sigma(I)$. For the ORTEP plot of the crystal structure see supporting info.

\subsection{Electrochemical activity measurement}

$\mathrm{CV}$ of the complex $\mathbf{3}$ was determined by the system of Zive SP1 Potentiostate/galvanostate. The measurement was performed using as $\mathrm{Ag} / \mathrm{AgCl}$ reference electrode with the three-electrode cell, a platinum rod for the working and counter electrode in the cell, by using acetonitrile and tetrabutylammoniumperchlorate (TBAP) electrolyte. The $\mathrm{CV}$ was performed within the range of 0 to $1.5 \mathrm{~V}$ with $200-400 \mathrm{mV} / \mathrm{s}$ rates.

\subsection{DFT calculations}

DFT optimization study of the produced material was made by the GAUSSIAN $09 \mathrm{~W}$ [13] software with the B3LYP (Becke, 3-parameter, Lee-Yang-Parr)/LanL2DZ (Los Alamos National Laboratory 2 Double Zeta) basis set. After that, the excited level, the energy level of HOMO and LUMO and electrostatic surface potential (ESP) values were calculated.

\subsection{Production of the Hybrid-Capacitor}

The complex 3 was used as an electrode material for a hybrid capacitor and CR2032 coin cell case was used for the measurements. The cell was designed as 
electrode/electrolyte/membrane(cellulose)/electrolyte/electrode. The samples used in the electrode fabrication were coated on $\mathrm{Ti}$ foil using a doctor blade and dried in vacuum oven at $100 \mathrm{C}$ and then it was punched to circular pieces of $8 \mathrm{~mm}$ diameter. The mixture for film was fabricated using $90 \%$ active material, $10 \%$ PVDF and enough amount NMP solvent. The purpose of using PVDF was a binder of coated film on Ti substrate. Afterwards, the heat treatment applied at $110^{\circ} \mathrm{C}$ to remove the solvent. $\mathrm{KOH}$ was selected as electrolyte material since it is the most used electrolyte material in capacitor systems, and, $6 \mathrm{~mol} \mathrm{KOH} / \mathrm{H}_{2} \mathrm{O}$ solutions were prepared as electrolyte for this experimental works. The Cyclic voltammetry measurements of complex $\mathbf{3}$ were performed by using Zive SP1 system. The CV of the capacitor cell in the CR2032 size was measured with two-electrode design and a constant current of $\pm 1 \mathrm{~mA}$ between -1 and $1 \mathrm{~V}$ with the rate of 200 and $400 \mathrm{mV} / \mathrm{s}$.

\subsection{Synthesis}

\subsubsection{Synthesis of 7-IPr.HBr,1}

The 7-IPr.HBr was synthesized according to literature [14]. The NMR results obtained are given below.

Yield: $2.79 \mathrm{~g}(56 \%)$. m.p. $259-260{ }^{\circ} \mathrm{C} .{ }^{1} \mathrm{H}$ NMR $\left(300 \mathrm{MHz}, \mathrm{CDCl}_{3}\right): \delta=1.17[\mathrm{~d}, J=6.8 \mathrm{~Hz}$, $12 \mathrm{H}, \mathrm{C}_{6} \mathrm{H}_{3}\left(\left(\mathrm{CH}\left(\mathrm{CH}_{3}\right)_{2}\right)_{2}-2,6\right], 1.40\left[\mathrm{~d}, \mathrm{~J}=12.7 \mathrm{~Hz}, 12 \mathrm{H}, \mathrm{C}_{6} \mathrm{H}_{3}\left(\left(\mathrm{CH}\left(\mathrm{CH}_{3}\right)_{2}\right)_{2}-2,6\right], 2.65\right.$ [bs, 4H, $\mathrm{NCH}_{2} \mathrm{CH}_{2} \mathrm{CH}_{2} \mathrm{CH}_{2} \mathrm{~N}$ ], 3.24 [sept., J=8 Hz, 4H, $\mathrm{C}_{6} \mathrm{H}_{3}\left(\left(\mathrm{CH}\left(\mathrm{CH}_{3}\right)_{2}\right)_{2}-2,6\right], 4.70$ [bs, 4H, $\mathrm{NCH}_{2} \mathrm{CH}_{2} \mathrm{CH}_{2} \mathrm{CH}_{2} \mathrm{~N}$ ], $7.24\left[\mathrm{~d}, J=8 \mathrm{~Hz}, 4 \mathrm{H}, \mathrm{C}_{6} \mathrm{H}_{3}\left(\left(\mathrm{CH}\left(\mathrm{CH}_{3}\right)_{2}\right)_{2}-2,6\right], 7.29\right.$ [s, $1 \mathrm{H}, \mathrm{NCHN}$, $7.42\left[\mathrm{t}, J=8 \mathrm{~Hz}, 2 \mathrm{H}, \mathrm{C}_{6} \mathrm{H}_{3}\left(\left(\mathrm{CH}\left(\mathrm{CH}_{3}\right)_{2}\right)_{2}-2,6\right] .{ }^{13} \mathrm{C}\{\mathrm{H}\} \mathrm{NMR}\left(75 \mathrm{MHz}, \mathrm{CDCl}_{3}\right): \delta=24.6\right.$ and $25.0\left[\mathrm{C}_{6} \mathrm{H}_{3}\left(\left(\mathrm{CH}\left(\mathrm{CH}_{3}\right)_{2}\right)_{2}-2,6\right], 24.9\left[\mathrm{C}_{6} \mathrm{H}_{3}\left(\left(\mathrm{CH}\left(\mathrm{CH}_{3}\right)_{2}\right)_{2}-2,6\right], 29.0\left[\mathrm{NCH}_{2} \mathrm{CH}_{2} \mathrm{CH}_{2} \mathrm{CH}_{2} \mathrm{~N}\right], 56.2\right.\right.$ $\left[\mathrm{NCH}_{2} \mathrm{CH}_{2} \mathrm{CH}_{2} \mathrm{CH}_{2} \mathrm{~N}\right], 125.3,130.9,138.9,144.9\left[\mathrm{C}_{6} \mathrm{H}_{3}\left(\left(\mathrm{CH}\left(\mathrm{CH}_{3}\right)_{2}\right)_{2}-2,6\right], 157.1\right.$ [NCHN] ppm. LC-MSMS (ESI): m/z 419.35 [M-Br] ${ }^{+}$(100\%) $\left(\mathrm{C}_{29} \mathrm{H}_{43} \mathrm{~N}_{2}\right.$ requires 419.35); Calcd for $\mathrm{C}_{29} \mathrm{H}_{43} \mathrm{~N}_{2} \mathrm{Br}$ : C, 69.72; H, 8.68; N, 5.61; Found C, 69.80; H, 8.72; N, 5.70. 


\subsubsection{Synthesis of Silver-NHC complex, 2}

The complex 2 was synthesized according to literature [14]. To synthesize complex 2 , $2 \mathrm{mmol} \mathrm{Ag}_{2} \mathrm{O}$ was added to the DCM solution of $\mathbf{1}(1 \mathrm{mmol})$ under exclusion of light. After stirring $24 \mathrm{~h}$ at $\mathrm{rt}$, reaction mixture filtrated upon a short pad of $\mathrm{SiO}_{2}$ and $\mathrm{DCM}$ removed under high vacuum. DCM/diethyl ether solution $(1: 2 \mathrm{v} / \mathrm{v})$ of 2 led to obtain white solid crystals for NMR and other analysis. The obtained NMR results are given below. NMR spectra of complex 2 was measured in DMSO- $\mathrm{d}_{6}$ to determine if complex 2 was formed. As is known, the $\mathrm{NCHN}$ proton comes to resonance together with aromatic protons on ${ }^{1} \mathrm{H}$ NMR in $\mathrm{CDCl}_{3}$. The ${ }^{1} \mathrm{H}$ NMR in DMSO-d 6 shifted $\mathrm{NCHN}$ proton to low field at ${ }^{1} \mathrm{H}$ NMR (see NMR data of complex $\mathbf{3}$ and compound $\mathbf{1}$ ).

Yield: $0.450 \mathrm{~g}(75 \%) .{ }^{1} \mathrm{H}$ NMR (400 MHz, DMSO-d 6$): \delta=1.28$ and 1.30 [d, $J=6.8 \mathrm{~Hz}, 24 \mathrm{H}$, $\mathrm{C}_{6} \mathrm{H}_{3}\left(\left(\mathrm{CH}\left(\mathrm{CH}_{3}\right)_{2}\right)_{2}-2,6\right], 2.26 \quad\left[\mathrm{~s}, \quad 4 \mathrm{H}, \quad \mathrm{NCH}_{2} \mathrm{CH}_{2} \mathrm{CH}_{2} \mathrm{CH}_{2} \mathrm{~N}\right], 3.28 \quad[\mathrm{p}, \quad J=6.8 \mathrm{~Hz}, 4 \mathrm{H}$, $\mathrm{C}_{6} \mathrm{H}_{3}\left(\left(\mathrm{CH}\left(\mathrm{CH}_{3}\right)_{2}\right)_{2} \quad-2,6\right], \quad 4.05 \quad\left[\mathrm{~s}, \quad 4 \mathrm{H}, \quad \mathrm{NCH}_{2} \mathrm{CH}_{2} \mathrm{CH}_{2} \mathrm{CH}_{2} \mathrm{~N}\right], \quad 7.25-7.36 \quad[\mathrm{~m}, \quad 6 \mathrm{H}$, $\mathrm{C}_{6} H_{3}\left(\left(\mathrm{CH}\left(\mathrm{CH}_{3}\right)_{2}\right)_{2}-2,6\right] . \quad{ }^{13} \mathrm{C} \quad\{\mathrm{H}\} \quad \mathrm{NMR} \quad\left(100 \quad \mathrm{MHz}, \quad \mathrm{DMSO}-\mathrm{d}_{6}\right): \delta=24.8$ and 24.9 $\left[\mathrm{C}_{6} \mathrm{H}_{3}\left(\left(\mathrm{CH}\left(\mathrm{CH}_{3}\right)_{2}\right)_{2}-2,6\right], \quad 25.2\left[\mathrm{C}_{6} \mathrm{H}_{3}\left(\left(\mathrm{CH}\left(\mathrm{CH}_{3}\right)_{2}\right)_{2}-2,6\right], \quad 28.5 \quad\left[\mathrm{NCH}_{2} \mathrm{CH}_{2} \mathrm{CH}_{2} \mathrm{CH}_{2} \mathrm{~N}\right], \quad 53.9\right.\right.$ $\left[\mathrm{NCH}_{2} \mathrm{CH}_{2} \mathrm{CH}_{2} \mathrm{CH}_{2} \mathrm{~N}\right], \quad 125.8, \quad 129.1, \quad 145.1 \quad\left[\mathrm{C}_{6} \mathrm{H}_{3}\left(\left(\mathrm{CH}\left(\mathrm{CH}_{3}\right)_{2}\right)_{2}-2,6\right]\right.$, ppm. Calcd for $\mathrm{C}_{29} \mathrm{H}_{42} \mathrm{~N}_{2} \mathrm{AgBr}$ : C, 57.44; H, 6.98; N, 4.62; Found C, 57.32; H, 6.89; N, 4.68.

\subsubsection{Synthesis of $\left[\mathrm{PtCl}_{3}(\mathrm{DMSO})\right]^{-}[\mathrm{NHC}]^{+}, \mathbf{3}$}

To synthesize complex $\mathbf{3}, 1 \mathrm{mmol} \mathrm{K}_{2}\left[\mathrm{PtCl}_{4}\right]$ was added to the DMSO solution of $\mathbf{2}$ under exclusion of light. After stirring $2 \mathrm{~h}$ at $80{ }^{\circ} \mathrm{C}$, reaction mixture was led to cool in room temperature and $60 \mathrm{~mL}$ acetone was added in order to precipitate the complex 3 . Filtration of solid upon filter paper and washing with acetone $(3 \times 10 \mathrm{~mL})$ gave complex as yellow-brown solid. DCM/diethyl ether solution $(1: 2 \mathrm{v} / \mathrm{v})$ of $\mathbf{3}$ led to obtain single crystals for $\mathrm{X}$ ray diffraction analysis. The synthesis pathway of complex $\mathbf{3}$ was given in Figure 1. 
Yield: $0.52 \mathrm{~g}(65 \%) .{ }^{1} \mathrm{H}$ NMR (400 MHz, DMSO-d 6$): \delta=1.23[\mathrm{~d}, J=6.8 \mathrm{~Hz}, 12 \mathrm{H}$, $\mathrm{C}_{6} \mathrm{H}_{3}\left(\left(\mathrm{CH}\left(\mathrm{CH}_{3}\right)_{2}\right)_{2}-2,6\right], 1.321 .40$ [d, J=6.8 Hz, 12H, $\mathrm{C}_{6} \mathrm{H}_{3}\left(\left(\mathrm{CH}\left(\mathrm{CH}_{3}\right)_{2}\right)_{2}-2,6\right], 2.37$ [bs, 4H, $\mathrm{NCH}_{2} \mathrm{CH}_{2} \mathrm{CH}_{2} \mathrm{CH}_{2} \mathrm{~N}$ ], 2,55 [s, $6 \mathrm{H}, \mathrm{Pt}\left(\mathrm{CH}_{3}\right)_{2} \mathrm{SO}$ ], 3.10 [p, J=6.7 Hz, 4H, $\mathrm{C}_{6} \mathrm{H}_{3}\left(\left(\mathrm{CH}_{\left.\left(\mathrm{CH}_{3}\right)_{2}\right)_{2-}-}\right.\right.$ 2,6], 4.28 [bs, 4H, $\left.\mathrm{NCH}_{2} \mathrm{CH}_{2} \mathrm{CH}_{2} \mathrm{CH}_{2} \mathrm{~N}\right], 7.35-7.48$ [m, 6H, $\mathrm{C}_{6} \mathrm{H}_{3}\left(\left(\mathrm{CH}\left(\mathrm{CH}_{3}\right)_{2}\right)_{2}-2,6\right], 8.68$ [s, $1 \mathrm{H}, \mathrm{NCHN}] .{ }^{13} \mathrm{C}\{\mathrm{H}\} \mathrm{NMR}\left(100 \mathrm{MHz}, \mathrm{CDCl}_{3}\right): \delta=24.6$ and $25.0\left[\mathrm{C}_{6} \mathrm{H}_{3}\left(\left(\mathrm{CH}\left(\mathrm{CH}_{3}\right)_{2}\right)_{2}-2,6\right]\right.$, 24.9[ $\mathrm{C}_{6} \mathrm{H}_{3}\left(\left(\mathrm{CH}\left(\mathrm{CH}_{3}\right)_{2}\right)_{2}-2,6\right], \quad 29.0 \quad\left[\mathrm{NCH}_{2} \mathrm{CH}_{2} \mathrm{CH}_{2} \mathrm{CH}_{2} \mathrm{~N}\right], 56.2 \quad\left[\mathrm{NCH}_{2} \mathrm{CH}_{2} \mathrm{CH}_{2} \mathrm{CH}_{2} \mathrm{~N}\right]$, 125.3, 130.9, 138.9,144.9 $\left[\mathrm{C}_{6} \mathrm{H}_{3}\left(\left(\mathrm{CH}\left(\mathrm{CH}_{3}\right)_{2}\right)_{2}-2,6\right], 157.1\right.$ [NCHN] ppm. HRMS (ES): $m / z$ $419.3431[\mathrm{M}-\mathrm{Br}]^{+}(100 \%)\left(\mathrm{C}_{29} \mathrm{H}_{43} \mathrm{~N}_{2}\right.$ requires 419.3421$) ; \mathrm{m} / \mathrm{z}$ 752,8464 $[\mathrm{M}-2 \mathrm{H}]^{+}(78.2 \%)$; $\left(\mathrm{C}_{29} \mathrm{H}_{41} \mathrm{~N}_{2} \mathrm{PtCl}_{4}\right.$ requires 752,1672).

\section{Results and Discussion}

\subsection{Synthesis and characterization}

The re- $N$-heterocyclic carbene precursor $\mathbf{1}$, has been synthesized according to literature. The obtained NMR data of 1 was compatible with the literature [14]. Upon formation of the reNHCs precursor, ${ }^{1} \mathrm{H}$ NMR spectroscopy revealed the appearance of the characteristic formamidinium salt $\mathrm{NCHN}$ proton at $7.29 \mathrm{ppm}$. This ${ }^{1} \mathrm{H}$ NMR shift of $\mathbf{1}$ was consistent with reported seven-membered NHC salts [15]. The ${ }^{13} \mathrm{C}$ NMR spectroscopy revealed the carben carbon of $1(\mathrm{NCHN})$ at $157.1 \mathrm{ppm}$.

Compound 1 was used for synthesis of silver-NHC complex 2 via $\mathrm{Ag}_{2} \mathrm{O}$ under exclusive of light in dried DCM. The ${ }^{1} \mathrm{H}$ and ${ }^{13} \mathrm{C}$ NMR spectra of complex 2 were recorded in $\mathrm{CDCl}_{3}$ and DMSO- $\mathrm{d}_{6}$ in order to clearly understand the transformation of 1 to 2 . The ${ }^{1} \mathrm{H}$ NMR spectra measured in DMSO-d 6 showed that characteristic $\mathrm{NCHN}$ proton signal totally disappeared. The $\mathrm{NC}_{2} \mathrm{~N}-\mathrm{Ag}$ carbon peak was not detected which is a known situation in the literature [14]. The complex 2 was characterized and used for the synthesis of complex $\mathbf{3}$.

Initially, the complex we aimed to synthesize was the [Pt(NHC) $\mathrm{Cl}_{2} \mathrm{DMSO}$ ]. Surprisingly, [7$\operatorname{IPr}]^{+}\left[\mathrm{PtCl}_{3}(\mathrm{DMSO})\right]^{-}$ionic complex was formed. In the formation of complex $\mathbf{3}$, we think that 
the moisture/water that can be present in the reaction medium or in DMSO is effective. During the transmetalation, re-N-heterocyclic carbene silver complexes can give reversible reaction and sometimes be converted to protonated form of NHC by transferring hydrogen from ambient moisture. According to literature, although there is not any platinum complex similar to the complex $\mathbf{3}$, there are couple of different type of ionic complexes of ruthenium and palladium [16]. The observation of $\mathrm{NCHN}$ proton on ${ }^{1} \mathrm{H}$ NMR of 3 in DMSO- $\mathrm{d}_{6}$ confirms the formation of $[7-\mathrm{IPr}]^{+}\left[\mathrm{PtCl}_{3}(\mathrm{DMSO})\right]^{-}$ionic complex. Also, resonance of $C_{2}$ carbon of reNHC on ionic $\mathrm{Pt}(\mathrm{II})-\mathrm{re}-\mathrm{NHC}$ complexes in ${ }^{13} \mathrm{C}$ NMR spectra not changed due to noncoordination to platinum centre (Figure 2). The hydrogens of coordinated DMSO was observed at $2.55 \mathrm{ppm}$ which is shifted to low field at ${ }^{1} \mathrm{H}$ NMR. The ${ }^{195} \mathrm{Pt}$ NMR spectra of complex $\mathbf{3}$ confirm that the compound $\mathbf{3}$ consist of one platinum fragment. In addition, the HRMS spectra was confirmed the proposed structures for the $\mathbf{3}$, recorded in methanol. The most intense peaks correspond to molecular fragment ionized by the $\left[\mathrm{PtCl}_{4}\right]^{2-}\left[\mathrm{C}_{29} \mathrm{H}_{43} \mathrm{~N}_{2}\right]^{2+}$ in positive-ion mode. In the HRMS spectra of complex 3, $\left[\mathrm{NHC}^{+},\left[\mathrm{C}_{29} \mathrm{H}_{43} \mathrm{~N}_{2} \mathrm{PtCl}_{4}-2 \mathrm{H}\right]^{+}\right.$and $\left[\mathrm{PtCl}_{4}\right.$ fragments were observed in the positive and negative MS mode.

\subsection{Crystallography}

According to ORTEP analysis, the molecular structure of the complex $\mathbf{3}$ which obtained experimentally is given in Figure 3 and it was also theoretically investigated by DFT calculations. The crystallographic results are juxtaposed with experimental data in Table 1 and they are compared with the theoretical results. It should be noted that the calculated and experimentally obtained crystallographic data were compatible with each other. For instance, it can be said that the experimental and computational bond lengths of Pt1-Cl3 and N13 - C14 were 2.3302-2.3806 $\AA$ and 1.461-1.4672, respectively. The experimentally obtained and 
calculated angles of C15 - C14- N13 and O51- S1- Pt1 were $118.6^{\circ}-118.907^{\circ}$ and $116.17^{\circ}$ $116.91^{\circ}$, respectively.

\subsection{HOMO/LUMO and ESP analysis}

The electronic structure of the complex was calculated by the DFT using the optimized structure as seen in the Figure 4a. Structural harmony was seen on the theoretically calculated and experimentally obtained values such as the angles and bond lengths of complex 3. It was used the B3LYP/LanL2DZ basis for energy calculation of the HOMO and the LUMO. The HOMO and LUMO energies were obtained as $-5.753 \mathrm{eV}$ and $-2.222 \mathrm{eV}$, respectively. The $\mathrm{E}_{\mathrm{g}}=(\mathrm{LUMO}-\mathrm{HOMO})$ of complex 3 was found as $3.531 \mathrm{eV}$.

The HOMO and LUMO states of the complex 3 were given in Figure $4 \mathrm{~b}$ and c. it should be noted that the decreasing the energy of the LUMO and increasing the energy of the HOMO may be explained by the decrease of the ionization energy of the complex 3 . According to $\mathrm{E}_{\mathrm{g}}$ value of the complex 3 , it can be said that the electron transfer in complex 3 is irrelevant.

Figure 5 shows the ESP results of the complex that the intense green color shows the positive electrostatic potential region and the red sink color corresponds to the negative electrostatic potential in the structure. According to ESP analysis, it is found that the positively charged area in the structure is lower than that of the negatively charged region in Figure 5. In addition to this, it should be noted that the complex $\mathbf{3}$ showed nucleophilic behavior which is reactive against electrophilic properties in the environment. The narrow electrophilic region of the complex can be explained by the poor attractive fields for negative charged environment, but the red colored region in ESP figure shows strong electrophilic properties on the region of the chloride ions in the structure.

\subsection{Redox properties}


It is well known that $\mathrm{CV}$ measurements are used for the determination of ionization energy, electron affinity and energy gap [17]. The CV measurement of the complex $\mathbf{3}$ was performed using a $0.05 \mathrm{M}$ acetonitrile solution of $n-\mathrm{Bu}_{4} \mathrm{NClO}_{4}$ as the supporting electrolyte including $0.05 \mathrm{mM}[7-\mathrm{IPr}]^{+}\left[\mathrm{PtCl}_{3}(\mathrm{DMSO})\right]^{-}$and the data was given in the Figure 6 . The redox peaks at CV graphs were obtained as $\mathrm{E}_{\mathrm{pa}}=0.292 \mathrm{~V}, \mathrm{E}_{\mathrm{Pc}}=1.211 \mathrm{~V}, \mathrm{E}_{1 / 2}=0.4595 \mathrm{~V}$ for the scan rate of $400 \mathrm{mV} / \mathrm{s}$ as seen in Table 2. It was predicted that the complexes showed redox peaks which correspond to the Pt(II)-Pt(IV) interconversion. Although it was seen one anodic and one cathodic peaks in $\mathrm{CV}$ graph, it should be noted that Pt complex exhibit a doubleelectron redox reaction from $\mathrm{Pt}(\mathrm{II})$ to $\mathrm{Pt}(\mathrm{IV})$ for the activation/deactivation process [18]. It may be interpreted that the excitations of the electrons in the complex may be observed at almost the same energy and it should gave rise to the peak broadening in the peaks of the CV data. In addition to this, the $\mathrm{Pt}^{2+}$ ions in the complex structure for square environment should split to 4 different energy levels and the ionization structure of $\mathrm{Pt}^{2+}$ to $\mathrm{Pt}^{4+}$ may be at the same energy since the highest occupied energy level of d-ions are paired electrons which shows a diamagnetic properties and the ionization energy of the paired electrons from d-level to vacuum are almost same.

The value of the $E_{P c}$ and $E_{p a}$ was varied by the ascending scan rate of the $C V$, which can be given with the Randles-Sevcik aproach which means that the peaks at CV are directly related to the square root of the scan rate. The oxidation potential of the structure can be given as below [19]:

$$
E_{O x}=E_{o x}^{l}+E_{A g / A g C l \simeq E_{o x}^{l}}+E_{\text {vacuum }}+4.4 \mathrm{~V}
$$

Where $E_{\text {vacuum }}$ is the energy of vacuum level and it may be taken as zero and $E_{o x}^{l}$ is the onset of oxidation potential. The ionization potential is equal to $e E_{O x}$ which can be calculated from eq.1. It should be noted that eq. 1 is a semi-empirical formula and it only gives an information for comparing the $\mathrm{CV}$ data. The HOMO and LUMO values were given a previous 
section and it is not well matched with the eq. 1 value since the last two term of the eq. 1 should be modified by each system.

\subsection{Performance Analysis of Capacitors}

It should be noted that the theoretical expectation of the CV data of a supercapacitor cell is a rectangle shape and the experimental measurements generally deviates from the expectation. The $\mathrm{CV}$ of the capacitor cell used complex $\mathbf{3}$ as the electrodes using 6 mol $\mathrm{KOH} / \mathrm{H}_{2} \mathrm{O}$ electrolyte solution was shown in Figure 7a. According to Figure $7 \mathrm{a}$, complex 3 has a rectangle $\mathrm{CV}$ shapes. 200 and $400 \mathrm{mV} / \mathrm{s}$ constant scan rates show us the complex 3 have the supercapacitor property.

Figure $7 \mathrm{~b}$ shows discharge characteristic data of the capacitors for range of $\pm 1 \mathrm{~V}$. It can be seen that the discharge data shows an exponential decay with increasing time as expected shape of a capacitor cell. The time for charging and discharging of the capacitor is directly proportional with the specific capacity of the cell, and it is shown in Figure $7 \mathrm{c}$ that the discharging time is shorter than charging time and it is an undesirable result in the structure.

The cell capacity of the cell was explained with the equation below :

$$
C=\frac{I \cdot m}{-\Delta \mathrm{V} / \Delta \mathrm{t}}
$$

where $\mathrm{m}$ is the mass of the material in the electrodes, $\mathrm{I}$ is the applied current which is constant for the measurement, $\Delta \mathrm{V} / \Delta \mathrm{t}$ is the gradient of the $\mathrm{CV}$ curve for charging and discharging in the cell. The capacity of the cells was measured over 1000 cycles, as seen in Figure $7 \mathrm{~b}$. The capacity during to charge/discharge process at the different cycles and the calculated capacity fade values of the cells are given in Table 3.

The first charge and discharge capacity values of complex 3 cells have showed 28.15 and $10.22 \mathrm{Fg}^{-1}$ respectively, and, which the values are almost similar range with the capacity 
value of a supercapacitors [20]. According to capacity fade values for long term cycle process, the complex 3 has showed too high capacity fade percentage after 1000 cycles with $96.83 \%$ and $92.66 \%$ for charge and discharge, respectively. Although the fade of capacity is high enough when compared with the material which was used as a capacitor, this is a key study for future investigations. So, we may suggest that the complex materials including metal ions may have a huge potential in capacitive type applications such as supercapacitors and we believe that these types of structures may be used as an electrode material of this type of energy storage applications in the next future after improving their capacitive properties.

\section{Conclusion}

The complex 3 was successfully produced and the structures experimental data was compared with the calculated data as given in Table 1. The calculated energy gap between HOMO and LUMO was found as $3.531 \mathrm{eV}$, which is important for electronic properties.

We used Cr2032 case for the production of a hybrid capacitor and the highest capacity value was found as $10.22 \mathrm{~F} / \mathrm{g}$, which has a potential for the capacitor studies of complex structures. It should be noted that the capacitive properties of Pt-complexes for energy technology are a new study area for organometallic industry, and it can be said that organometallic complex materials may be used as a capacitor material and electronic circuit in the next future.

In this study, structural properties are investigated using single crystal XRD and DFT suit. The electrochemical activity of the complex and the capacitive properties were investigated in detail and it is found that the complex has a potential for the energy storage materials in portable devices and electronic circuits.

\section{Appendix A. Supplementary data}

CCDC 1845130 contains the supplementary crystallographic data for compound $\mathbf{3}$. These data 
can be obtained free of charge via http://www.ccdc.cam.ac.uk/conts/retrieving.html, or from the Cambridge Crystallographic Data Centre, 12 Union Road, Cambridge CB2 1EZ, UK; fax: (+44) 1223-336-033; or e-mail: deposit@ccdc.cam.ac.uk.

\section{Acknowledgement}

Dr. Serdar Altin want to thanks to Inönü University for the financial support with project numbers of G- 2016/52 for the measurement of the electrochemical and capacitive properties of complex.

\section{References}

[1] L. L. Zhanga, and X. S. Zhao, Chem Soc Rev. 38 (2009) 2520-2531.

[2] F. Beguin, and E. Frackowiak, Supercapacitors: Materials, systems and applications, Wiley, Germany, 2013.

[3] (a) S. Niwa. Synfh. Met., 18 (1987) 665-670; (b) H. Yamamoto, M. Fukuda, I. Isa, K. Yoshino, Trrrns. Inst. Elec on. fnj: Commun. Eng. Jpn., /75-C-11, 12 (1992) 745; (c) J. Kyokane, K. Yoshino , Journal of Power Sources 60 (1996) 151-155; (d) M. Akkoç, E. Öz, S. Demirel, V. Dorcet, T. Roisnel, A. Bayri, C. Bruneau, S. Altin, S. Yaşar, I. Özdemir, J. Organomet. Chem. 866 (2018) 214-222.

[4]For selected books and recent reviews, see: (a) F. N. Glorius, Heterocyclic Carbenes in Transition Metal Catalysis, Springer-Verlag, Heidelberg, Germany, 2007. (b) M. N. Hopkinson, C. Richter, M. Schedler, F. Glorius, Nature, 510 (2014) 485-496; (c) V. Ce’sar, S. Bellemin-Laponnaz, L. H. Gade, Chem. Soc. Rev. 33(2004) 619-636; (d) F. E. Hahn, and M. C. Jahnke, Angew. Chem., Int. Ed., 47 (2008) 3122-3172; (e) S. D1'ezGonza'lez, N. Marion and S. P. N. Nolan, Chem. Rev. 109 (2009) 3612-3676 (f) J. C. Y. 
Lin, R. T. W. Huang, C. S. Lee, A. Bhattacharyya, W. S. Hwang, I. J. B. Lin, Coinage Chem. Rev. 109 (2009) 3561-3598; (g) P. L. Arnold, I. J. F. Casely, Chem. Rev. 109 (2009) 3599-3611.

[5](a) L. Benhamou, E. Chardon, G. Lavigne, S. Bellemin-Laponnaz, V. César, Chem. Rev. 111 (2011) 2705-2733; (b) A. John, P. Ghosh, Dalton Trans. 39 (2010) 7183-7206; (c) W. Kirmse, Angew. Chem. Int. Ed. 49 (2010) 8798-8801.

[6](a) M. Iglesias, D. J. Beestra, A. Dervisi, I. A. Fallis, K. J. Cavell, Organometallics, 26 (2007) 4800-4809; (b) M. Iglesias, D. J. Beestra, B. Kariuki, K. J.Cavell, A. Dervisi, I. A. Fallis, Eur. J. Inorg. Chem. 13(2009) 1913-1919; (c) A. Binobaid, M. Iglesias, D. J Beestra, B. Kariuki, A. Dervisi, I. A. Fallis, K. J. Cavell, Dalton Trans. 35 (2009) 70997112; (d) P. D. Newman,; K. J. Cavell, B. M. Kariuki, Organometallics, 29 (2010) 27242734; (e) E. L. Kolychev, I. A. Portnyagin Shuntikov, V. Khrustalev, M. S. Nechaev, J. Org. Chem., 694 (2009) 2454-2462; (f) R. S. Holdroyd, M. J. Page, M. R. Warren, M. K. Whittlesey, Tetrahedron Lett., 51 (2010) 557-559.

[7](a) E. Ö. Karaca, M. Akkoç, E. Öz, S. Altin, V. Dorcet, T. Roisnel, N. Gürbüz, Ö. Çelik, A. Bayri, C. Bruneau, S. Yaşar, and I. Özdemir, J. Coord. Chem., 70 (2017) 1270-1284; (b) E. Ö. Karaca, M. Akkoç, M. N. Tahir, C. Arıcı, F. İmik, N. Gürbüz, S. Yaşar, İ. Özdemir, Tetrahedron Lett., 58 (2017) 3529-3532; (c) Q. Teng, W. Wu, H. A. Duong, H. V. Huynh, Chem. Commun., 54 (2018) 6044-6047; (d) X. Wang, J. Liu, J. Yu, L. Hou, W. Sun, Y. Wang, S. Chen, A. Li,W. Wang, Inorg. Chem., 57 (2018) 2969-2972.

[8](a) C. C. Scarborough, I. A. Guzei, S. S. Stahl, Dalton Trans., 13 (2009) 2284-2286 (b) C. C. Scarborough, A. Bergant, G. T. Sazama, I. A. Guzei, L. C. Spencer, S. S. Stahl, Tetrahedron 65 (2009) 5084-5092; (c) C.C. Scarborough, M. J. W. Grady, I. A. Guzei, B. A. Gandhi, E. E. Bunel, S. S. Stahl, Angew. Chem. Int. Ed. 44 (2005) 5269-5272. 
[9] S. Di'ez-Gonza'lez, N-Heterocyclic Carbenes: From Laboratory Curiosities to Efficient Synthetic Tools, RSC Publishing, Cambridge, UK, 2011.

[10](a) W. Y. Lu, K. J. Cavell, J. S. Wixey, B. M. Kariuki, Organometallics 30 (2011) 56495655 (b) J. Dunsford, K. J. Cavell, Organometallics, 33 (2014) 2902-2905 (c) G. Altenhoff, R. Goddard, C. W. Lehmann, F. Glorius, Angew. Chem. Int. Ed. 42 (2003) 3690-3693; (d) S. Wurtz, F. Glorius, Acc. Chem. Res.41 (2008) 1523-1533.

[11] G. M. Sheldrick, Acta Cryst. A71 (2015) 3-8

[12] G.M. Sheldrick, Acta Cryst. C71 (2015) 3-8.

[13] M. J. Frisch, G. W. Trucks, H. B. Schlegel, G. E. Scuseria, M.A. Robb Gaussian 09, Revision D.01, Gaussian, Inc., Wallingford, CT, 2009.

[14] M. Iglesias, D. J. Beetstra, J. C. Knight, L. L. Ooi, A. Stasch, S. Coles, L. Male, M. B. Hursthouse, K. J. Cavell, A. Dervisi, I. A. Fallis, Organometallics, 27 (2008) 3279-3289.

[15] M. Iglesias, D. J. Beetstra, K. J. Cavell, A. Dervisi, I. A. Fallis, B. Kariuki, R. W. Harrington, W. Clegg, P. N. Horton, S. J. Coles, M. B. Hursthouse, Eur. J. Inorg. Chem. 11(2010) 1604-1607.

[16](a) H. Arslan, D. VanDerveer, İ. Özdemir, N. Gürbüz, Y. Gök, B. Çetinkaya, Acta Cryst. E65 (2009) m165-m166; (b) F. Schroeter, J. Soellner, T. Strassner, ACS Catal.7 (2017) 3004-3009; D. Meyer, M. A. Taige, A. Zeller, K. Hohlfeld, S. Ahrens, T. Strassner, Organometallics, 28 (2009) 2142-2149; (c) X. Zhang, Q. Xia, W. Chen, Dalton Trans. 35 (2009) 7045-7054; (d) X. Yang, Z. Fei, T. J. Geldbach, A. D. Phillips, C. G. Hartinger, Y. Li, P. J. Dyson, Organometallics, 27 (2008) 3971-3977; (e) S. K. Kariofillis, L. A. Cesanek, W. S. Kassel, N. A. Piro, R. J.L. Swails, Polyhedron, 114 (2016) 317-324.

[17] B. W. D’Andrade, S. Datta, S. R. Forrest, P. Djurovich, E. Polikarpov, M. E. Thompson, Organic Elec. phys. mater. appl. 6 (2005) 11-20. 
[18] (a) S. Choi, L. Vastag, Y. C. Larrabee, M. L. Personick, K. B. Schaberg, B. J. Fowler, R. K. Sandwick, G. Rawji, Inorg. Chem., 47 (2008) 1352-1360; (b) M. A. Bennett, S. K. Bhargava, A. M. Bond, A. J. Edwards, S.-X. Guo, S. H. Prive'r, A. D. Rae, A. C. Willis, Inorg. Chem., 43 (2004) 7752-7763.

[19] F. N. Crespilho, V. Zucolotto, J. R., Siqueira, A. J. F. Carvalho, F. C. Nart, O. N. Oliveira, Int. J. Electrochem. Sci. 1(2008) 151-159

[20] L. Chang, J. Li, X. Duan, W. Liu, Electrochimica Acta, 176 (2015) 956-964

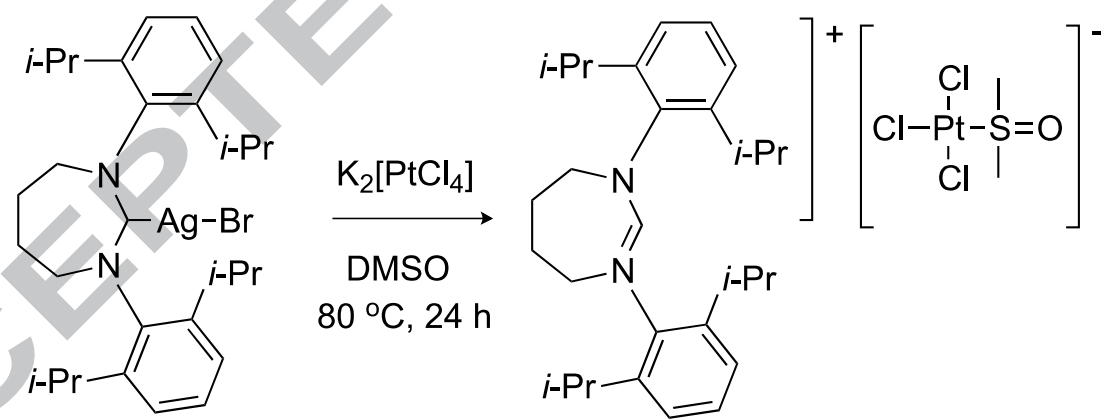

Figure 1. Synthesis of complex 3 . 


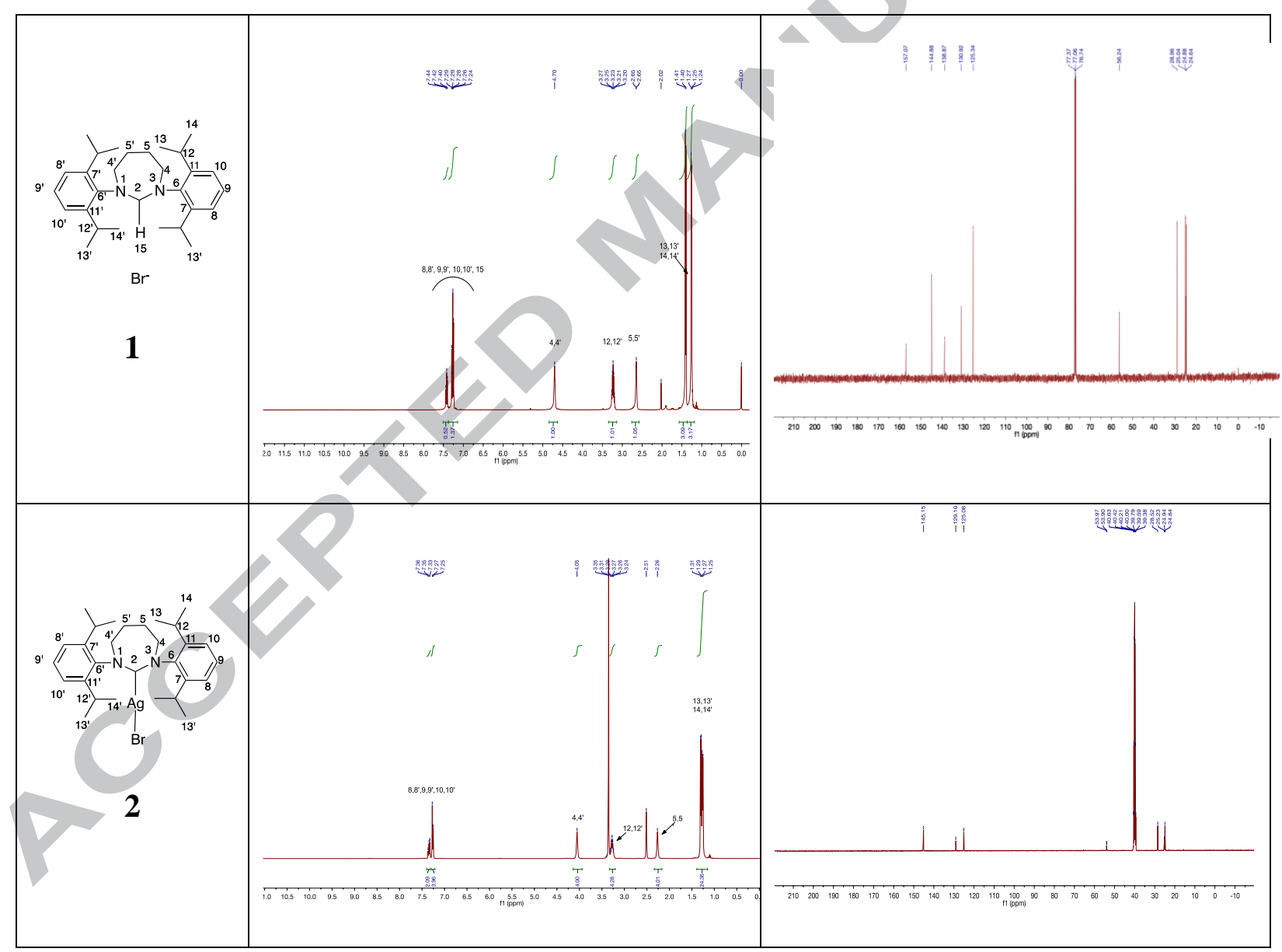




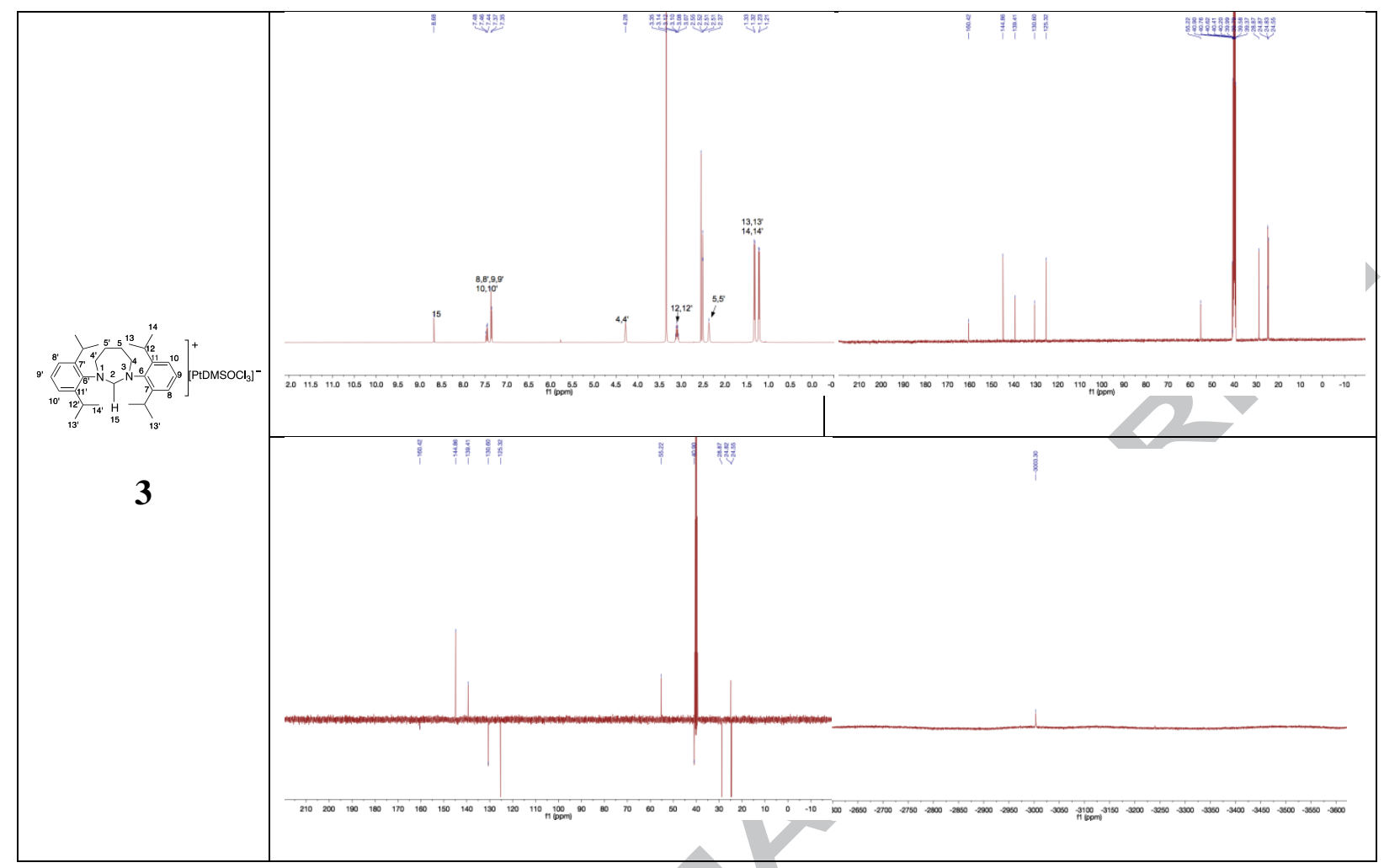

Figure 2 The NMR spectra of compound 1, 2, and $\mathbf{3}$.

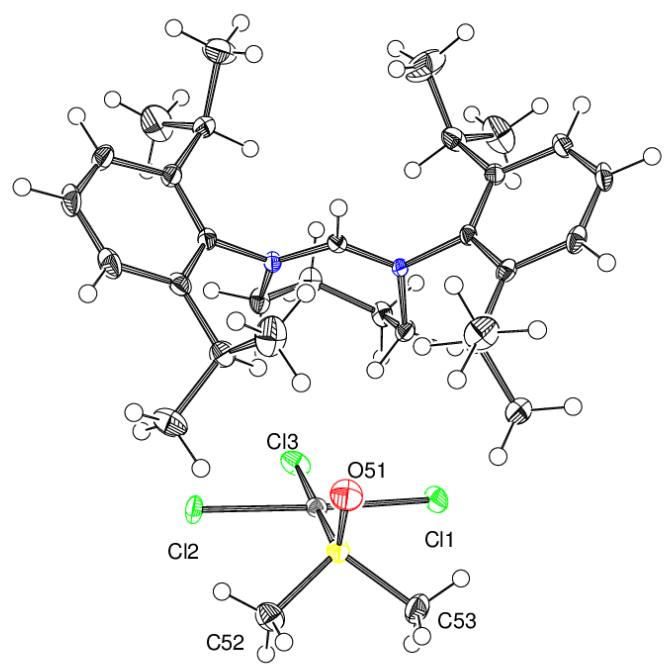

Figure 3. ORTEP drawing of a molecule of complex 3, as present in crystal at $\mathrm{T}=150 \mathrm{~K}$ (CPK coloring convention is used; ellipsoid probability level for non- $\mathrm{H}$ atoms $=$ 
$50 \%)$. Selected bond lengths $\left[\mathrm{A}^{\circ}\right]:$ Pt $1-\mathrm{S} 1=2.2093(10), \mathrm{Pt} 1-\mathrm{C} 11=2.3234(9), \mathrm{Pt} 1-\mathrm{Cl} 3=$ 2.3302(9), Pt1- Cl2= 2.3328(9), C1- N33= 1.315(4), C1- N13=1.317(4), C1- H1=0.9500. Selected bond angles $\left[{ }^{0}\right]:$ S1- Pt1- Cl1 $=90.02(3), \mathrm{S} 1-\mathrm{Pt} 1-\mathrm{Cl} 3=179.03(3), \mathrm{Cl1}-\mathrm{Pt1}-\mathrm{Cl} 3=$ 89.99(4), S1- Pt1- Cl2= 91.92(3), Cl1- Pt1- Cl2= 177.14(3), Cl3- Pt1- Cl2= 88.03(4), N33$\mathrm{C} 1-\mathrm{N} 13=126.9(3), \mathrm{N} 33-\mathrm{C} 1-\mathrm{H} 1=116.6$. 


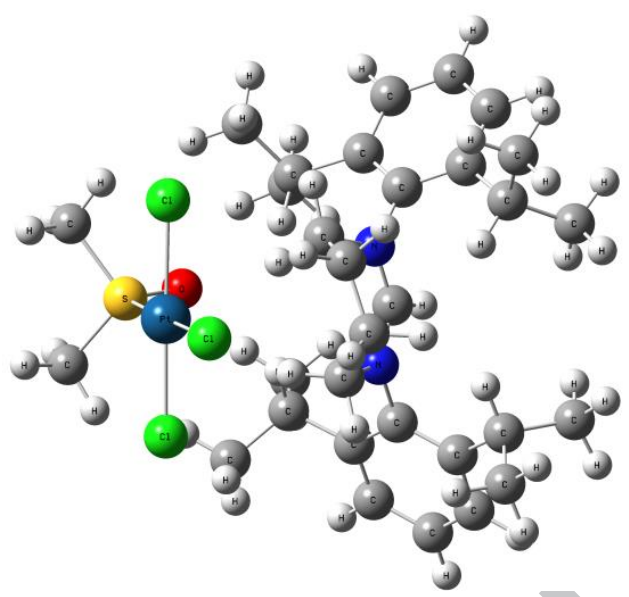

(a)

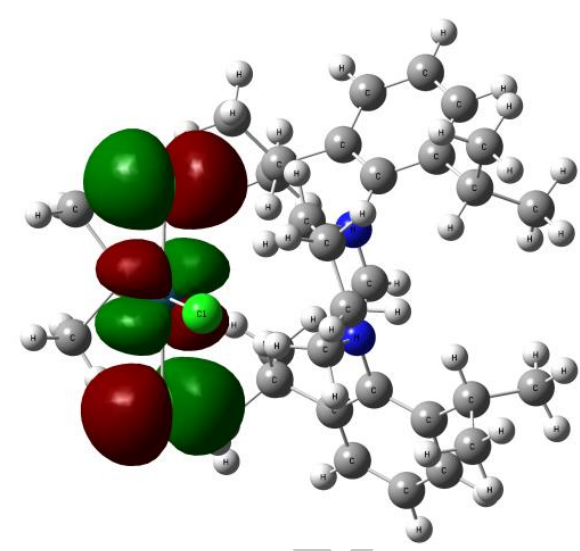

(b)

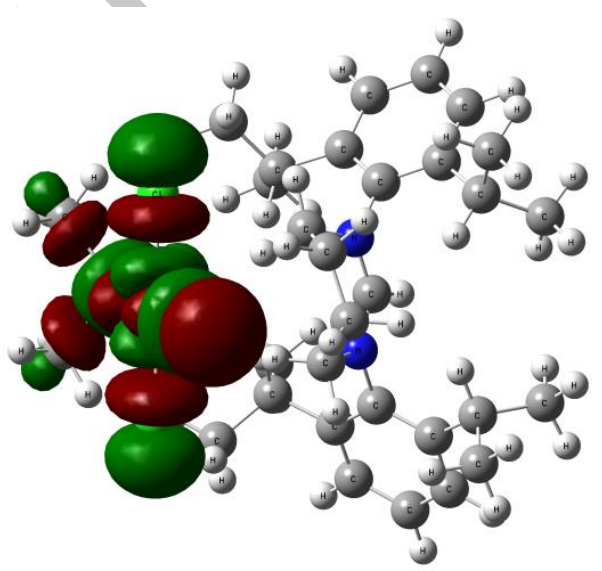

(c)

Figure 4. (a) Optimized molecule, (b) HOMO and (c) LUMO state by DFT calculation of complex 3 . 


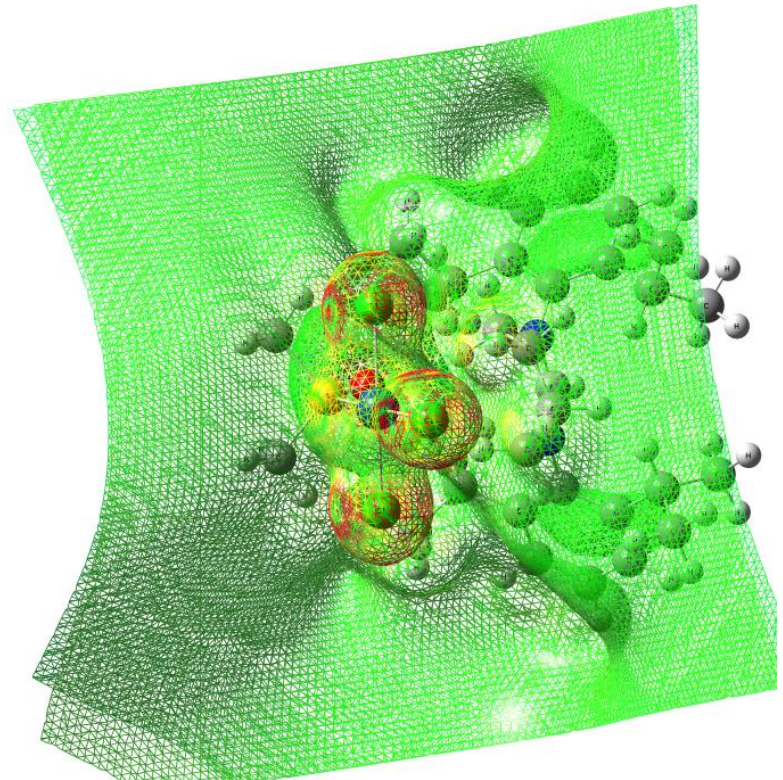

(a)

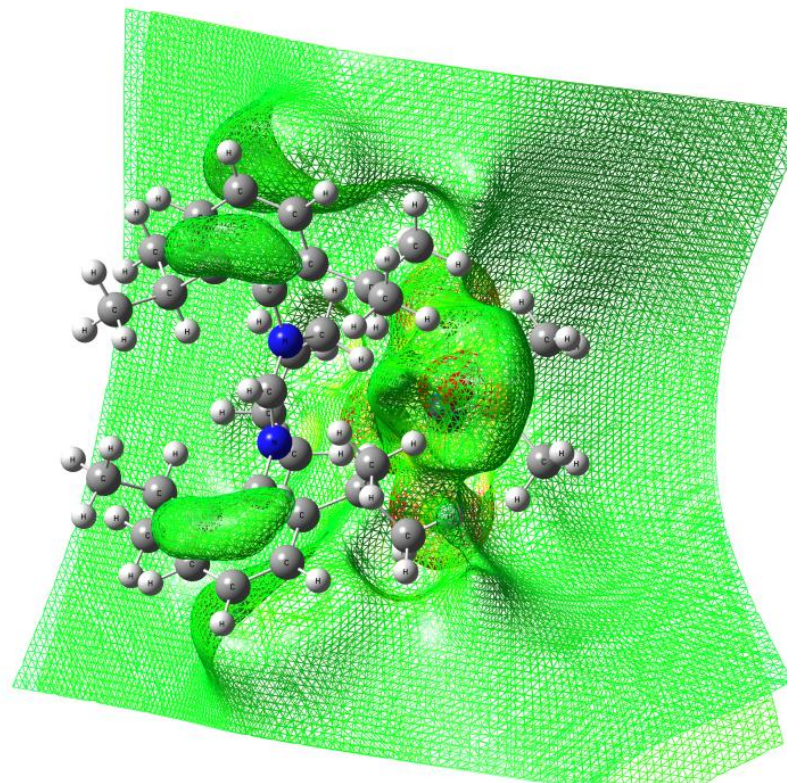

(b)

Figure 5. (a) front and (b) back view of ESP of the complex (green color indicates neutral charge density. The blue and red colors indicate the positive and negative charge densities, respectively) 


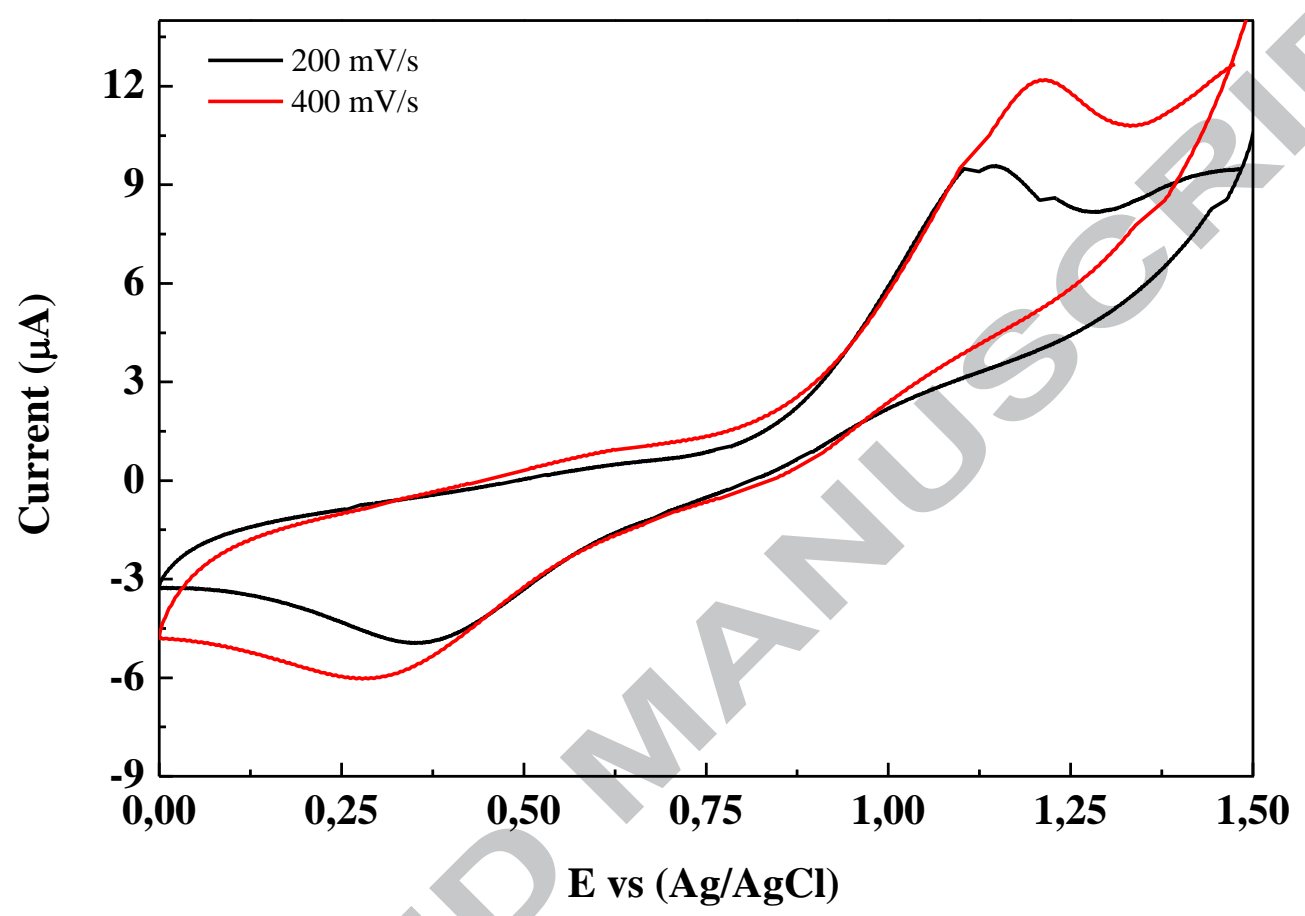

Figure 6. CV of the complex 3 at different scan rates 


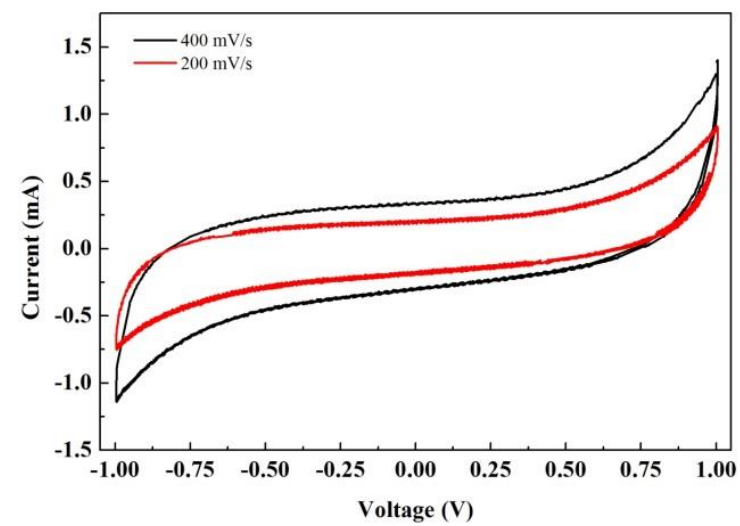

(a)

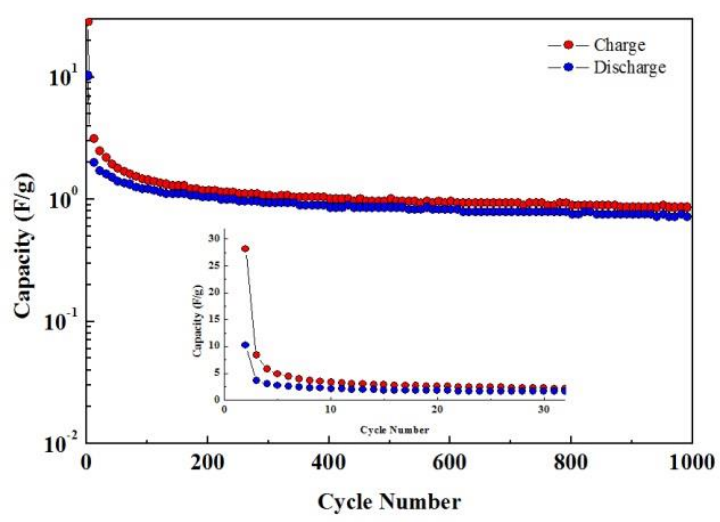

(b)

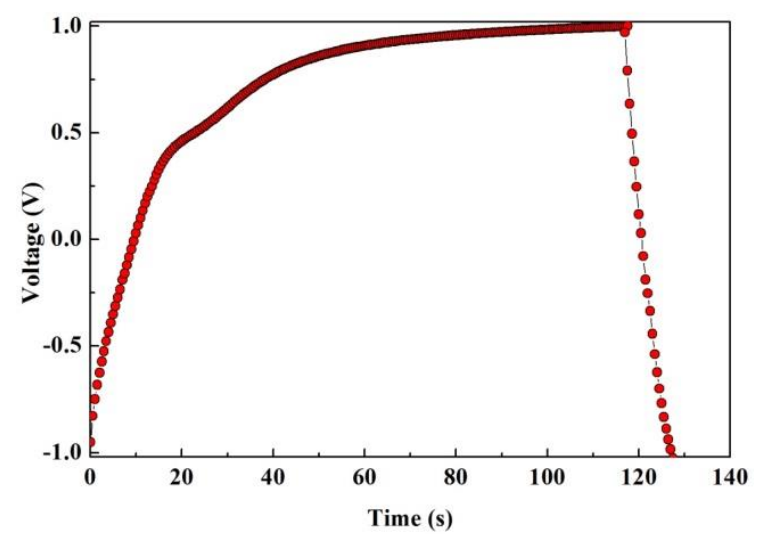

(c)

Figure 7. (a) CV measurements of complex 3 at different scan rates, (b) Capacity-Cycle measurements and (c) Time dependence charge-discharge characteristics of the complex 
Table 1. Analogy of experimental and theoretical computation bond length and angle results of the complex 3

\begin{tabular}{|c|c|c|c|c|c|c|c|c|}
\hline & \multicolumn{2}{|c|}{ Bond Leghts (Å) } & & \multicolumn{2}{|c|}{ Angles $\left({ }^{\circ}\right)$} & & \multicolumn{2}{|c|}{ Torsion angles $\left({ }^{\circ}\right)$} \\
\hline & Found & Calcd. & & Found & Calcd. & & Found & Calcd. \\
\hline Pt1-S1 & 2.2093 & 2.4178 & S1- Pt1- Cl1 & 90.02 & 88.474 & C31-C11-C12-N13 & -52.0 & -54.89 \\
\hline $\mathrm{Pt} 1-\mathrm{Cl} 1$ & 2.3234 & 2.4404 & S1- Pt1- $\mathrm{Cl} 3$ & 179.03 & $\begin{array}{l}178.11 \\
6\end{array}$ & N33-C1-N13-C14 & 173.0 & 173.22 \\
\hline $\mathrm{Pt} 1-\mathrm{Cl} 3$ & 2.3302 & 2.3806 & $\mathrm{Cl} 1-\mathrm{Pt} 1-\mathrm{Cl} 3$ & 89.99 & 91.359 & N33-C1-N13-C12 & -13.3 & -11.13 \\
\hline $\mathrm{Pt} 1-\mathrm{Cl} 2$ & 2.3328 & 2.4393 & S1-Pt1- Cl2 & 91.92 & 89.082 & C11-C12-N13-C14 & -111.9 & -115.45 \\
\hline S1 - O51 & 1.471 & 1.6871 & O51-S1-C52 & 108.2 & 105.88 & C34-C35-С36-C37 & 1.1 & 0.871 \\
\hline $\mathrm{S} 1-\mathrm{C} 52$ & 1.773 & 1.8885 & O51-S1-C53 & 108.12 & 105.44 & C38-C39-C40-C41 & -61.8 & -67.97 \\
\hline S1 - C53 & 1.777 & 1.8884 & O5-S1-Pt1 & 116.17 & 116.91 & C14-C19-C23-C25 & 105.6 & 112.61 \\
\hline $\mathrm{C} 1-\mathrm{N} 33$ & 1.315 & 1.3373 & C52- S1-Pt1 & 111.76 & 112.96 & & & \\
\hline $\mathrm{C} 1-\mathrm{N} 13$ & 1.317 & 1.3356 & N13-C12-C11 & 113.4 & $\begin{array}{l}114.10 \\
4\end{array}$ & & & \\
\hline $\mathrm{C} 12-\mathrm{N} 13$ & 1.484 & 1.5079 & C1-N13-C14 & 119.2 & 118.55 & & & \\
\hline N13-C14 & 1.461 & 1.4672 & C1-N13-C12 & 122.3 & $\begin{array}{l}123.18 \\
4\end{array}$ & & & \\
\hline C14-C15 & 1.398 & 1.4211 & C15-C14-N13 & 118.6 & $\begin{array}{l}118.90 \\
7\end{array}$ & & & \\
\hline C14-C19 & 1.407 & 1.4214 & C19-C14-N13 & 117.6 & $\begin{array}{l}118.64 \\
5\end{array}$ & & & \\
\hline C20 -C21 & 1.528 & 1.5511 & C14-C15-C16 & 117.2 & $\begin{array}{l}117.65 \\
8\end{array}$ & & & \\
\hline $\mathrm{C} 20-\mathrm{C} 22$ & 1.521 & 5523 & N33-C32-C31 & 113.3 & $\begin{array}{l}113.40 \\
8\end{array}$ & & & \\
\hline C23-C25 & 1.524 & 1.5525 & C1-N33-C34 & 118.3 & 117.47 & & & \\
\hline $\mathrm{C} 43-\mathrm{C} 45$ & 1.525 & 1.5501 & C1-N33-C32 & 125.4 & $\begin{array}{l}125.51 \\
7\end{array}$ & & & \\
\hline C34 -C35 & 1.392 & 1.4197 & C35-C34-N33 & 118.7 & $\begin{array}{l}118.78 \\
1\end{array}$ & & & \\
\hline
\end{tabular}


Table 2. CV properties of the complex $\mathbf{3}$ on different scan rates

\begin{tabular}{|l|l|l|l|}
\hline Scan Rates $(\mathbf{m V} / \mathbf{s})$ & $\mathrm{E}_{\mathrm{Pc}}(\mathrm{eV})$ & $\mathrm{E}_{\mathrm{Pa}}(\mathrm{eV})$ & $\mathrm{E}_{1 / 2}(\mathrm{eV})$ \\
\hline $\mathbf{4 0 0}$ & 1.211 & 0.292 & 0.7515 \\
\hline $\mathbf{2 0 0}$ & 1.127 & 0.359 & 0.743 \\
\hline
\end{tabular}


Table 3. Charge-discharge capacity values and discharge capacity fading rate results for complex $\mathbf{3}$ materials.

\begin{tabular}{|c|c|c|c|c|c|c|c|c|}
\hline \multirow{2}{*}{$\underline{\text { Status }}$} & \multirow{2}{*}{$\begin{array}{c}\mathbf{1}^{\text {st }} \text { Cycle } \\
\text { Capacity } \\
\text { (F/g) }\end{array}$} & \multicolumn{2}{|c|}{$100^{\text {th }}$ Cycle } & \multicolumn{2}{|c|}{$250^{\text {th }}$ Cycle } & \multicolumn{2}{|c|}{$500^{\text {th }}$ Cycle } & \multirow{2}{*}{$\begin{array}{l}1000^{\text {th }} \text { Cycle } \\
\text { Capacity } \quad \text { C.F }\end{array}$} \\
\hline & & $\begin{array}{c}\text { Capacity } \\
\text { (F/g) }\end{array}$ & $\begin{array}{l}\text { C.F } \\
\%\end{array}$ & $\begin{array}{c}\text { Capacity } \\
(\mathrm{F} / \mathrm{g})\end{array}$ & $\begin{array}{l}\text { C.F } \\
\%\end{array}$ & $\begin{array}{c}\text { Capacity } \\
\text { (F/g) }\end{array}$ & $\begin{array}{c}\text { C.F } \\
\%\end{array}$ & \\
\hline Charge & 28.15 & 1.42 & 94.95 & 1.14 & 95.95 & 0.99 & 96.48 & 96.83 \\
\hline Discharge & 10.22 & 1.21 & 88.16 & 0.96 & 90.6 & 0.85 & 91.68 & 92.66 \\
\hline
\end{tabular}



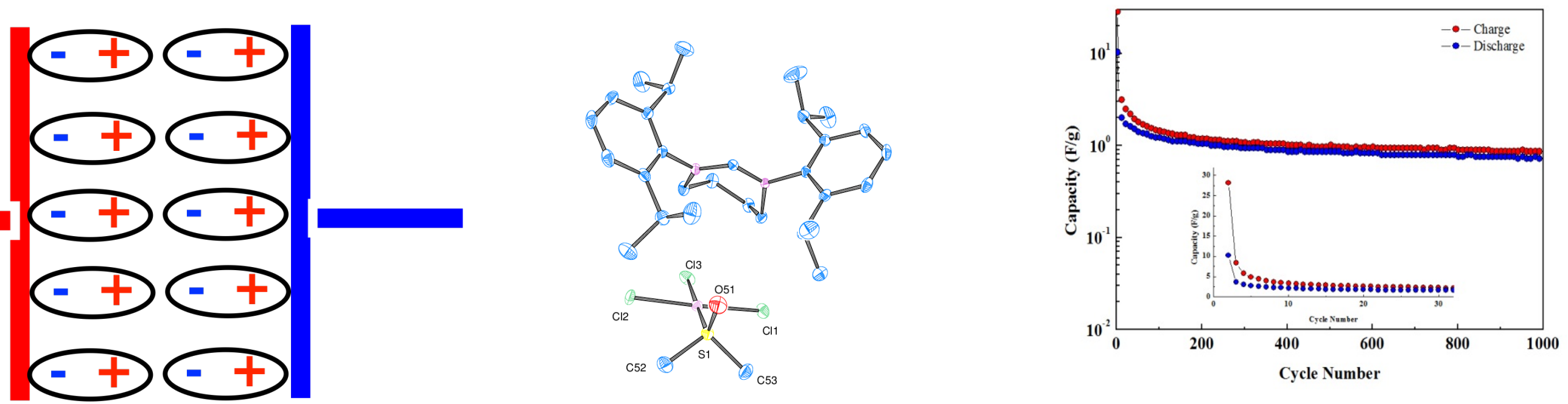